DOI 10.15393/j9.art2019.5861

УДК 821.161.1.09“1917/1992”

Дарья Борисовна Терешкина

(Великий Новгород, Российская Федерация)

terdb@mail.ru

\title{
Еванге иские образы и мотивы в первой книге «Братских песен» Николая Клюева
}

Аннотация. Статья предлагает анализ первой книги «Братских песен» Николая Клюева (1912) с точки зрения отражения в ней Евангелия. Будучи высоко оцененной сразу после выхода, книга песен стала выражением идеологии одного из важных религиозных направлений в русской мысли начала XX в. - «голгофских христиан» (к нему прямо отсылает подзаголовок книги). Призыв к деятельной любви и добровольному самопожертвованию во имя Царствия Божьего на земле становится главной идеей «Братских песен». Распятие христиан вслед за Христом, крестные муки и преображение последователей Иисуса составляют главные образы книги песен, в которой соединились разнородные устные, литературные, иконографические традиции. Евангельские мотивы в тексте книги песен представляют объединяющую основу идеи и художественного мира книги.

Ключевые слова: Евангелие, голгофские христиане, иконографичность, цитата, образ, мотив, лейтмотив

$\mathrm{B}$ 1912 г. в издательстве журнала «Новая земля» вышла неболышая книга стихов Николая Клюева «Братские песни»1. Она сразу стала событием в русской литературе. Об этом говорит факт выхода второй книги «Братских песен»² в том же году, расширенной за счет включения двух десятков стихотворений, не вошедших в первую книгу, и дополненной болышой хвалебной статьей Валентина Свенцицкого [Свенцицкий]. Исследователи определяют творчество Н. Клюева как «маргинальное» среди существовавших в 1910-х гг. поэтических школ [Солнцева: 98]. Однако в русле активного богоискательства 1910-х гг. он был не только «своим» для «новых христиан» самого разного толка, но и своего рода «пророком» среди так называемых «голгофских христиан», группировавшихся вокруг журнала «Новая земля» во главе с Ионой Брихничевым, Михаилом Старообрядческим и Валентином Свенцицким. Как отмечал В. Г. Базанов, «этот 
полурелигиозный полусветский еженедельник, возглавлявшийся Брихничевым, выступал против “лампадного православия", против официальной церкви, проповедуя так называемую “религию свободы”, цель которой, как ее неоднократно определял журнал, заключалась в защите угнетенных, в подвижнической борьбе за социальную справедливость и нравственное совершенство» [Базанов]. Несмотря на противоречивые оценки творчества Н. Клюева (в том числе его «Братских песен») и современниками поэта (А. Блоком, В. Брюсовым, Д. Мережковским и др.) (см.: [Байнин]), и читателями последующих эпох, оно, несомненно, - яркое явление в русской литературе. А при ближайшем рассмотрении - и глубокое (см., напр.: [Доманский], [Семенова]).

«Братские песни» представляют собой книгу стихотворных текстов, каждый из которых, являясь самостоятельным произведением, составляет общий сюжет (см.: [Барковская] и др.). В первой редакции таких текстов девять, и именно этот состав является наиболее цельным и совершенным. Сюжет «Братских песен» в его «спрямленном» виде можно представить следующим образом: ожидание пришествия Христа во славе теми, кто в Него верит как в Бога Живого и проходит Его путь крестных страданий во искупление грехов других людей. Евангельский текст книги создается обилием евангельских мотивов, вплетенных в поэтический и символический язык «Братских песен», и может быть сам по себе интерпретирован как Евангелие, переживаемое в настоящем: Христос живет всегда среди братьев-христиан, и ожидание Его - это не Апокалипсис, а предвкушение всеобщей встречи, даже для тех, кто со Спасителем не пребывает ежечасно.

В. Свенцицкий в предисловии ко второй книге «Братских песен» чрезвычайно высоко оценил творение Клюева, которого он считал поэтом, ставшим пророком, а сами «Песни» «пророческим гимном Голгофе» [Свенцицкий: V]. Одним из идеологов «голгофских христиан» сразу был понят основной посыл книги: “"Освобождение земли” на языке религиозном должно быть названо искуплением <...>. Не дано “искупление” как подвиг единого Агнца - оно дастся как усилие всей земли» [Свенцицкий: VII]. В. Свенцицкий видит в этом усилии 
предвестие нового учения о всеобщей ответственности за все и за всех и о новой жизни («в новой плоти, неподчиненной законам тления и смерти» [Свенцицкий: XI]).

Ожидание Второго пришествия Христа, ставшего главной темой книги «Братские песни», логично было бы соотносить с «Откровением Иоанна Богослова», однако с ним в поэтике книги гораздо меньше связи, чем с Евангелием. Именно евангельские мотивы и само Евангелие как Благая Весть о пришедшем в мир его Спасителе становятся конструирующей моделью поэтического мира книги.

Мир клюевских песен чрезвычайно самобытен, как мировоззрение и религиозность самого Клюева (см.: [Калинина: 58]). «В свой духовный мир он (Н. Клюев. - Д. Т.) стянул огромные величины: культуру фольклора, церковной литургики (эстетического богословия), старообрядчества, сектантства, прежде всего опыт хлыстовского мистицизма и, наконец, активнохристианскую мысль Н. Ф. Федорова. Поразительное сочетание двух последних влияний явил уже второй сборник поэта “Братские песни” (1912)» [Семенова, № 1: 331]. Лирическое «Я» «Братских песен» заменяется соборным «мы»; всё, что в них звучит, можно назвать лирическим голосом - имея в виду, однако, что это голос многосоставного хора (не случайно песнь VII разделена на две части, где вторая отделена от первой указанием, как для хора в церковном богослужении: «Возглас второй»). Этот собор «братьев-христиан» неустойчив в своем составе и может включать в себя как всех христиан и прощенных ими врагов, так и одного «пророка», ведущего ко Христу маловерных.

Книга «Братские песни» состоит из девяти частей (песен). Начинается она с описания мира, где живут братья по вере. Этот мир приобретает черты Эдема, ибо природа (узнаваемая читателем как реальная, с русскими чертами) изображена как храм,

$$
\begin{aligned}
& \text { «... где зори - свечи, } \\
& \text { Где предалтарный фимиам - } \\
& \text { Туманы дремлющих поречий» }
\end{aligned}
$$

Все люди для лирического субъекта - братья, и их он зовет «К нам - в нетленный сад, под кипарисы» (4). В этом образе 
локус, где пребывают братья, узнаваем как рай, причем не тот, первозданный и утерянный человеком, а тот, который, согласно народным преданиям, сохранился на земле (см.: [Образ рая...], [Мильков]). Люди в этом земном раю - те, что знают Христа и прошли страдания вместе с Ним. Они хранят ключи от ада, их город берегут «братья-воины», и всякий, кто без вражды приходит в город, - «собрат» им. «Мы» - это «соратники Христовы, / Преисподней ключари» (5). Раскрыть ад дано лишь им - перед тем, как Христос придет во славе, а «не в нищенском хитоне / И не с терном вкруг чела» (5). IV песнь книги - это молитва братии «Невечернему Свету» перед испытанием - подобно молитве Христа в Гефсиманском саду в ночь перед Распятием (Мф. 26:36-46; Мк. 14:33-42; Лк. 22:4046). Песнь $V$ изображает братский сбор - своего рода Тайную Вечерю, но без Христа. VI песнь - встреча с Христом, пришествие Спасителя. Общий суд превращается в суд частный, а лирический голос соборного «мы» сменяется лирическим «я» героя, вставшего с «сестрой» перед престолом и с нею же прощенного «за подвиг любви»:

«И пойму я, что минуло царство могилы, Что за гробом припал я к бессмертья ключу. Воспаришь ты к лазури, светла, шестикрыла, Молоньей просияв, я вослед полечу» (11).

VII песнь может быть охарактеризована как «гимн глашатаев Христа», песнь VIII - «Песнь похода» тех, кто уже на пути к Христу и кто ждет прихода других, в том числе убийц, прощенных вечной жизнью:

«Гробовой избегнув клети,

Сопричастники живым,

Мы убийц своих приветим

Целованием святым...» (14).

Заключительная, IX песнь книги - «Песнь утешения» остающимся жить, чтобы укрепляться в вере «у Христовых чистых ног», ибо им еще предстоит своя «Песнь похода».

Евангельские мотивы в виде аллюзий на события, происходившие при земной жизни Спасителя, создают устойчивое ощущение живого присутствии Христа в настоящем. 
Образ Христа «Пастырь добрый» (Ин. 10:11-16) появляется в III песне в самый драматичный момент: когда братия страждет на Голгофском кресте («Перебиты наши голени и ребра. / Ей, гряди ко стаду, Пастырь добрый!» - 6). Образ Доброго пастыря перекликается с упоминанием в этой же части Христа - Жертвенного Агнца: «Укрепитеся, собратья, хлебомсолью, / Причаститеся незримой Агнчей Кровью» (6). «Агнцем Божьим» называет Христа Иоанн Креститель в присутствии своих учеников в Евангелии от Иоанна: «На другой день видит Иоанн идущего к нему Иисуса и говорит: вот Агнец Божий, Который берет на Себя грех мира» (Ин. 1:29); «На другой день опять стоял Иоанн и двое из учеников его. И, увидев идущего Иисуса, сказал: вот Агнец Божий» (Ин. 1:35-36). Слова об Агнце несколько раз встречаются в «Откровении Иоанна Богослова», но именно евангельский рассказ созвучен песне клюевского цикла, в котором Христос представлен не ожидаемым, а живым, идущим к Своим ученикам.

«Братья» как герои и составляющие лирического голоса в книге песен представлены учениками Христа. И не только духовными (кем можно назвать всех христиан), но и прямыми, современниками Христа, избранными Им:

«Как рыбачили в водах Генисарета:

Где Ты, - Альфа и Омега, Отче Света?

Свет явился, рек нам: “Мир вам, други”!

Мы оставили мережи и лачуги

И пошли вослед Любови-Света» (9).

Акт призвания Христом учеников созвучен евангельским словам о призвании рыбаков (Мф. 4:18-22; Мк. 1:16-20; Лк. 5:1-11). Рассказ синоптических Евангелий о том, как Христос встречает братьев Симона-Петра и Андрея и возвещает им, что они будут «ловцами человеков», «сворачивается» в песни Клюева к краткому приветствию Спасителя и безоговорочному следованию Ему братьев (без указания имен и числа их, а потому символически обозначающему весь сонм безымянных христиан). Синкретизм использования поэтом библейского текста проявляется в свободном переплетении разных его частей. Слова Господа «Аз есмь Альфа и Омега» с проречением от первого лица читаются в «Откровении Иоанна Богослова» 
(Откр. 1:8, 10-11; 21:6-7; 22:12-13), а в «Братских песнях» звучат из уст идущих вослед за Христом; Сам Спаситель называется именами, которые применимы не собственно к Сыну Божьему, а к Всеединому Триипостасному Богу. Подобное обращение к Новозаветному тексту представляется естественным настолько, насколько органичным является восприятие Евангелия не как сюжетного текста, а как Благой Вести о вневременно́м пришествии Христа к людям.

VI песнь книги излагает заповеди блаженства как свершающиеся во Втором пришествии Христа (Мф. 5:3-12; Лк. 6:2023):
«Он затопчет, как сон, вероломства законы, Духом уст поразит исполинов-бойцов, Даст державу простым, и презренным - короны, Чтобы царством владели во веки веков...» (10-11).

В «Братских песнях» содержатся аллюзии на Евангельский текст, причем в очень вольной интерпретации. Однако, учитывая многозначность слов, используемых поэтом (и «короны», и «державу» можно понять по-разному), можно констатировать многослойность смысла текста и его, подобно Евангелию, не буквальный, а символический смысл.

В системе евангельских мотивов текста лейтмотивом выступает распятие Христа и смерть Христа на Кресте. Только это уже не распятие Спасителя, а крестные муки Его последователей:

«Разделяют с нами брашна серафимы,

Осеняют нас крылами легче дыма,

Сотворяют с нами знамение-чудо,

Возлагают наши душеньки на блюдо.

Дух возносят, серафимы, к Саваофу,

Телеса - на Иисусову Голгофу.

Мы в раю вкушаем ягод грозди, -

На земле же терпим крест и гвозди.

Перебиты наши голени и ребра...

Ей, гряди ко стаду, Пастырь добрый!» (6). 
В этих строках отчетливо звучит указание на двуединую природу человека: Дух его - у Господа, тело - на земле в страданиях. И, в отличие от Христа, тело Которого осталось целым, Его последователи-братия, как разбойники, были сокрушены телом и возопили, как Христос на Кресте возгласил «Боже Мой, Боже Мой! Для чего Ты Меня оставил?» (Мф. 27:46), только они взывают к самому Христу, как к Пастырю охраняемого Им стада:
«Чем смертельней терн и гвозди,
Тем победы ближе час...
Дух животными крылами
Прикоснется к мертвецам,
И завеса в пышном храме
Раздерется пополам...» (14).

Таким образом словно совершается круг искупительной жертвы: вслед за Иисусом страдают за грехи Его «братья»последователи, и, как Он, они готовы простить своих убийц во имя вечной жизни («Отошли от нас болезни, смерть и старость» - 6). «У Клюева же с удивительной силой передан главный, откровенный мотив активно-христианской, голгофской мысли: финальное прощение самых страшных грешников, полное искупление зла, причем с тончайшим, истинно Христовым пониманием» [Семенова, № 1: 336]. С этой же точки зрения - учеников - представлено и Преображение Господне в последней песни книги - «Песни утешения»:
«Что, собратья, приуныли,
Оскудели моготой?
Расплесните перья крылий,
Просияйте молоньей. -
Красотой затмите зори,
Славу звезд, луны чертог,
Как бывало на Фаворе
У Христовых, чистых ног» (16).

О Преображении Господнем, свершившемся при трех любимых учениках Иисуса - Петре, Иоанне и Иакове, - сообщают все синоптические Евангелия (Мф. 17:1-6; Мк. 9:1-8; Лк. 9:28-36), за исключением названия горы, которое известно из Священного Предания. И вновь, как в изображении 
Распятия, центром совершающегося становятся ученики Христа. Это они, вслед за Иисусом, озарятся Фаворским светом, они должны явить присутствие Божественного Духа в естестве - и тем заслужить свою Песнь Похода в Царствие Небесное.

Как справедливо утверждает С. Семенова, «"Братские песни” устремлены от этого мира, где “Смерти плен железный”, к Тому, Кто поможет “порвать навсегда" этот плен, вывести в свет преображения. При всецелой обращенности к концу, к переходу в иное бытие, этот переход мыслится не столько как внешняя грозная катастрофа, сколько как внутреннее преображение» [Семенова, № 1: 334].

Мотив, ставший в книге песен лейтмотивом, - ключи от ада, которые, будучи изначально у Христа (Откр. 1:17-18), теперь находятся у «братьев-ключарей»: «Поручил ключи от ада / Нам Вселюбящий стеречь» (4). Это они, остающиеся на земле и осознающие, что ад после Христа пополняется новыми грешниками, призваны сокрушить врата преисподней, взяв на себя грехи ее пленников, простив их силой Христовой любви во имя жизни вечной:
«Наш удел - венец терновый
Ослепительней зари,
Мы соратники Христовы,
Преисподней ключари» (4-5).

Утверждая первичность евангельских аллюзий в книге песен, С. Семенова пишет: «Образ сокрушения ада, не раз возникающий в творчестве Клюева, обличает в нем истинно новозаветную душу, из тех, что исповедует полноту восстанавливающих и жизнетворческих потенций в христианстве» [Семенова, № 1: 336].

Этот мотив прямо перекликается с упоминающимися в книге песен ключами от рая: «Звякнул ключ гостеприимный / У предвечных рая врат» (5). Николай Клюев словно остается в рамках народной традиции понимания перехода в Царствие Небесное: оно, если на то будет Божья воля, открывается ключом, данным, как известно по Священному Преданию и иконографическим образам, апостолу Петру. В этой широкой традиции отражено буквальное понимание евангельских слов: 
«...и Я говорю тебе: ты - Петр, и на сем камне Я создам Церковь Мою, и врата ада не одолеют ее; и дам тебе ключи Царства Небесного: и что́ свяжешь на земле, то́ будет связано на небесах, и что́ разрешишь на земле, то́ будет разрешено на небесах» (Мф. 16:18-19). В клюевской книге песен апостол Петр прямо не упоминается, и этим словно создается параллельный образ «братьев-ключарей», кому завещано хранить ключи от рая. Иерархическая система мира, в которой человек замкнут между двумя границами - верхней и нижней, - словно разрывается у Клюева самим человеком, ибо, в отличие от простодушного народного толкования образа врат, «Братские песни» постулируют высший смысл сказанных Иисусом слов. Этот смысл заключен не в непосредственной передаче ключей как предмета, а в наследовании божественного ключа духовного, при помощи которого отворяются все двери, раскрываются все души, сокрушаются грехи и распростирается человек для благодати. Именно этот ключ нужен человеку, чтобы не уповать на восшествие в Царствие Небесное, а приближать Царствие Божие на земле. В этом состоял весь смысл активного христианства. В этой, поэтически обыгранной омонимичности, выразил Клюев свои чаяния вечной жизни:

«И пойму я, что минуло царство могилы, Что за гробом припал я к бессмертья ключу.

Воспаришь ты к лазури, светла, шестикрыла, Молоньей просияв, я вослед полечу» (11).

«Работничество» в деле обретения людьми Христа выражено у Клюева в образах привычного крестьянского труда пахоты и молотьбы:

«Наша нива - тверди круг

Колосится звездной рожью,

И лежит вселенский плуг

У Господнего подножья.

Уж отточены серпы

Для новины лучезарной,

Скоро свяжется в снопы

Колос дремлюще-янтарный!» (12). 
Входящий в седьмую песнь книги, «второй возглас» этой части призывает «первенцев Адама» выйти в мир, данный им Богом, его преобразователями, а не изгнанниками из рая. Сделать эту землю подвластной человеческой созидательной мощи, после того, как сам человек очистился страданием, задача «братьев-христиан». И в этом у них не должно быть ни страха, ни сомнения, ибо «но Иисус сказал ему: никто, возложивший руку свою на плуг и озирающийся назад, не благонадежен для Царствия Божия» (Лк. 9:62). Обращая внимание на самобытный символизм именно этой части книги песен, С. Семенова замечает: «Свое видение Клюев разворачивает мощно и самобытно, без всякой тени философско-поэтической риторики, в свойственной ему космически-крестьянской символизации, когда предмет земледельческого обихода (“плуг”) вырастает в планетарно-вселенский масштаб. Гигантские плуг и пахота - образ тяжкого труда всей Земли, всех сынов человеческих <...> в общем деле преображения мира, искупления зла (“ада”), изведения оттуда всех его пленников» [Семенова, № 1: 337].

Иконографичная по своей поэтике, книга песен прямо отсылает к известным иконографическим сюжетам: призвание рыбаков, «Пастырь добрый», «Преображение Господне», «Иов на гноище», «Сошествие во ад», «Распятие», «Тайная вечеря», «Сошествие Святого Духа», «Христос во славе», а также центральному образу Литургии, изученному в свое время Л. А. Успенским [Успенский], и к иконографическим образам (Серафимам, архангелам, всему «небесному иконостасу»).

В системе евангельских образов и мотивов книги песен Клюева главным является символ Божественной Евхаристии. К Тайной Вечере отсылает V песнь (Мф. 26:17-30; Мк. 14:12-26; Лк. 22:7-39), Литургию с причастием описывает песнь I книги: «...вкусить кровей, живого хлеба» (3). «Живой хлеб» - центральный символ молитвы перед литургией. В целом хронотоп «Братских песен» является литургическим по своему главному значению. Божественная литургия как постоянное «воспоминание» о присутствии Христа соединяется с творческим актом воспроизведения изображения событий. Пришествие Христа предстает не как грядущее действо, с которым наступит 
конец мира, а как происходящее сейчас - для тех, кто Христа ощущает живым без конца и без времени. Он призывает учеников, Он дает им Свое Тело и Кровь, Он приходит во славе, как Царь - и все это происходит сейчас. Как писал архимандрит Киприан (Керн), «мирянин не присутствует, а активно, молитвенно переживает совершающуюся литургическую, голгофскую драму и причащается» [Киприан (Керн)]. Евхаристия сама по себе является символом искупительной жертвы: «Она вневременна, и в своей вневременности охватывает в одном моменте и прошлое, и настоящее, и будущее. Мы в ней “воспоминаем” и творение мира, и искупление человечества Сыном Божиим, и Его Крест, и Воскресение, Его вознесение и имеющее еще быть Второе и Страшное Пришествие» [Киприан (Керн)].

Именно это, евангельское, т. е. со-присутственное Христу, понимание искупительной жертвы человечества свойственно поэтике «Братских песен» Николая Клюева. Верно понятый еще с появлением первого издания главный смысл этой книги по прошествии почти ста лет не меняет своей сути и только обрастает дополнительными уровнями и слоями. В цикле «Братские песни» Клюев поэтически говорит о новом понимании искупления. Оно, по мысли поэта, не возложено целиком на Сына Божьего, принявшего на Себя все грехи человечества, а принято всеми людьми как обязательство прийти к Богу, самим пострадав на кресте - только не как Христос, а как разбойники, с Ним на Голгофе распятые. Только тогда Евангелие может быть понято человечеством во всей полноте своего смысла.

\section{Примечания}

1 Клюев Н. Братские песни (Песни голгофских христиан). М.: К Новой Земле, 1912.16 с.

2 Клюев Н. Братские песни (Книга вторая) / вступ. ст. В. Свенцицкого. М.: Новая земля, 1912. 61 с.

3 Клюев Н. Братские песни (Песни голгофских христиан). М.: К Новой земле, 1912. С. 3. Далее ссылки на это издание приводятся в тексте статьи с указанием страницы в круглых скобках. 


\section{Список литературы}

1. Базанов В. Г. С родного берега: О поэзии Н. Клюева / В. Г. Базанов; отв. ред. А. И. Павловский; АН СССР, Ин-т рус. лит. (Пушкин. дом). Л.: Наука, 1990. - 241 с. [Электронный ресурс]. — URL: https://www. booksite.ru/klyuev/4_6_04.html (03.02.2019).

2. Байнин С. В. Критика «первой волны» эмиграции о творчестве Н. А. Клюева // Apriori. Серия: Гуманитарные науки. - 2015. — № 3. C. 5 [Электронный ресурc]. - URL: http://www.apriori-journal.ru/ seria1/3-2015/Bajnin.pdf (07.02.2019).

3. Барковская Н. В., Верина У. Ю., Гутрина Л. Д. Книга стихов как теоретическая проблема // Филологический класс. - 2014. - № 1 (35) [Электронный ресурс]. - URL: https://cyberleninka.ru/article/n/knigastihov-kak-teoreticheskaya-problema (13.01.2019).

4. [Доманский В. А.] Николай Клюев: образ мира и судьба: науч. сб. / отв. ред. В. А. Доманский. - Томск; СПб.: Изд. Дом ТГУ, 2013. Вып. 4. -288 c.

5. Калинина Л. Ф. «Правнук Аввакума» («поэтический космос» Н. А. Клюева) // Вестник Башкирского университета. - 2007. - Т. 12. — № 2. C. $58-61$.

6. Киприан (Керн), Архимандрит. Евхаристия [Электронный ресурс]. URL: https://azbyka.ru/otechnik/Kiprian_Kern/evharistija/ (07.02.2019).

7. Мильков В. В. Концепция земного рая в древнерусских апокрифах // Апокрифы Древней Руси: Тексты и исследования. - М.: Наука, 1997. C. 229-254.

8. Образ рая: от мифа к утопии. Серия «Simposium». - СПб.: СанктПетербургское философское общество, 2003. - Вып. 31. - 256 с.

9. Свенцицкий В. Вступительная статья // Клюев Н. Братские песни (Книга вторая). - М.: Новая земля, 1912. - С. III-XIV.

10. Семенова С. Г. Поэт «поддонной» России (Религиозно-философские мотивы творчества Николая Клюева) // Молодая гвардия. - 1998. № 1. - С. 331-351; № 2. - С. 254-263; № 3. - С. 242-255.

11. Солнцева Н. М. Клюев Николай Алексеевич (1884-1937) // Литературная энциклопедия русского зарубежья: в 4 т. / под ред. Николюкина А. Н. Центр гуманитарных научно-информационных исследований, Отдел литературоведения ИНИОН РАН. - М., 2002. - Т. 1. - С. 97-101.

12. Успенский Л. А. Богословие иконы православной церкви. - Париж: Изд-во Западно-Европейского экзархата Московского Патриархата, 1989. - 474 c.

Информация об авторе: Терешкина Даръя Борисовна, - доктор филологических наук, профессор Российской академии народного хозяйства и государственной службы при Президенте РФ (РАНХиГС) (Филиал в г. Великий Новгород). 


\title{
The Gospel Images and Motifs in the First Book of the "Brotherly Songs" by Nikolai Klyuev
}

\begin{abstract}
The article offers the analysis of the first book of the "Brotherly songs" by Nikolai Klyuev (1912) with regard to the reflection of Gospel in it. Being highly appreciated immediately after its publication, the book of songs became an expression of the ideology of one of the important religious trends in Russian thought of the beginning of the 20th century - "Calvary Christians" (the subtitle of the book explicitly refers us to it). An appeal to an efficient love and voluntary self-sacrifice in the name of the Kingdom of God on earth becomes the main idea of the "Brotherly songs". The crucifixion of the Christians following the Crucifixion of Jesus Christ, the Passions and the Transfiguration of the adepts of Jesus constitute the main images of the book of songs, which comprised a variety of oral, literary and iconographic traditions. The Gospel motifs in the text of the book of songs represent a unifying basis of the idea and the artistic world of the book.
\end{abstract}

Keywords: Gospel, Calvary Christians, iconography, quotation, image, motif, leitmotif

\section{References}

1. Bazanov V. G. S rodnogo berega: O poezii N. Klyueva [From the Native Shores: About Poetry of N. Klyuev]. Leningrad, Nauka Publ., 1990. 241 p. Available at: https://www.booksite.ru/klyuev/4_6_04.html (accessed on February 3, 2019). (In Russ.)

2. Baynin S. V. Criticism of the "First Wave" of Emigration on the Works of N. A. Klyuev. In: Apriori. Seriya: Gumanitarnye nauki [Apriori. Series: Humanities], 2015, no. 3, p. 5. Available at: http://www.apriori-journal.ru/ seria1/3-2015/Bajnin.pdf (accessed on February 7, 2019). (In Russ.)

3. Barkovskaya N. V., Verina U. Yu., Gutrina L. D. The Book of Verses as a Theoretical Problem. In: Filologicheskiy klass, 2014, no. 1 (35). Available at: https://cyberleninka.ru/article/n/kniga-stihov-kak-teoreticheskaya-problema (accessed on January 13, 2019). (In Russ.)

4. Domanskiy V. A. Nikolay Klyuev: obraz mira i sud'ba: nauchnyy sbornik [Nikolai Klyuev: The Image of the World and Destiny: Collection of Studies]. Tomsk, St. Petersburg, Tomsk State University Publ., 2013, issue 4. 288 p. (In Russ.)

5. Kalinina L. F. "Great-grandson of Avvakum" ("A Poetic Space" of N. A. Klyuev). In: Vestnik Bashkirskogo universiteta [Bulletin of Bashkir University], 2007, vol. 12, no. 2, pp. 58-61. (In Russ.)

6. Kiprian (Kern), Archimandrite. Evharistiya [Eucharist]. Available at: https://azbyka. ru/otechnik/Kiprian_Kern/evharistija/ (accessed on February 7, 2019). (In Russ.) 
7. Mil'kov V. V. The Concept of Earthly Paradise in the Ancients Apocrypha. In: Apokrify Drevney Rusi: Teksty i issledovaniya [The Apocrypha of Ancient Russia: Texts and Researches]. Moscow, Nauka Publ., 1997, pp. 229-254. (In Russ.)

8. Obraz raya: ot mifa $k$ utopii. Seriya «Simposium» [The Image of Paradise: from Myth to Utopia. Series "Simposium"]. St. Petersburg, St. Petersburg Philosophy Society Publ., 2003, issue 31. 256 p. (In Russ.)

9. Sventsitskiy V. An Introductory Article. In: Klyuev N. Bratskie pesni (Kniga vtoraya) [Klyuev N. Brotherly Songs (Book Two)]. Moscow, Novaya zemlya Publ., 1912, pp. 3-14. (In Russ.)

10. Semenova S. G. The Poet of "Subbottom" Russia (Religious and Philosophical Motifs in the Works of Nikolai Klyuev). In: Molodaya gvardiya, 1998, no. 1, pp. 331-351; no. 2, pp. 254-263; no. 3, pp. 242-255. (In Russ.)

11. Solntseva N. M. Klyuev Nikolai Alekseevich (1884-1937). In: Literaturnaya entsiklopediya russkogo zarubezhya: $v 4$ tomakh [A Literary Encyclopedia of the Russian Expatriate Community: in 4 Vols]. Moscow, 2002, vol. 1, pp. 97-101. (In Russ.)

12. Uspenskiy L. A. Bogoslovie ikony pravoslavnoy tserkvi [Theology of the Icon of the Orthodox Church]. Paris, Patriarchal Exarchate in Western Europe (Moscow Patriarchate) Publ., 1989. 474 p. (In Russ.)

Information about the author: Tereshkina Daria B. - Doctor of Philology, Professor of The Russian Presidential Academy of National Economy and Public Administration under the President of the Russian Federation or RANEPA (Branch in Novgorod the Great).

Received: January 10, 2019

Date of publication: March 29, 2019 